\title{
Social movements in Contemporary Portugal
}

\author{
Célia Taborda Silva \\ Ph.D in Contemporary History \\ University Lusófona of Porto, Portugal \\ celiatsilva@sapo.pt
}

\begin{abstract}
This paper focuses in transformation of Portuguese society throughout the analysis of social movements. Social movements in Portugal were changing as the evolution of society. Throughout the ages, according to circumstances of each historical period protest as changing. in the early nineteenth century, the transition from the Old Regime to Liberalism sparked riots. The protests were dominated by the peasants, motivated by the introduction of liberalism and capitalism, which have transformed the traditional way of living. The late nineteenth and early twenty centuries brought the claim of the labor movement and unionism with the consequent organization of social events, such as strikes. The industrialization of the country created a great social inequality between the factory owners and workers, the latter living in precarious conditions which led to revolt. Between 1933 and 1974 the Portuguese dictatorship dominated the political system but even the social repression prevented the existence of strikes and demonstrations due to hunger. After 1974, the country resumes freedom but political and social democratization brought much dispute motivated by the opening of society to the global world.
\end{abstract}

Keywords: Portugal, social movements, historical evolution, protest

\section{Introduction}

This paper describes how social movements have changed in the contemporary era in Portugal, alongside the political, economic, and social changes that have occurred in the country, and intends to verify whether these movements have also been an engine of this same transformation.

The perspective of the analysis is historiographic rather than sociological; therefore, the concept of social movement is to be understood as any collective act carried out by a social group (Tilly, 1978). We have also considered the opinion of Maria Glória Gohn, who classifies social movements as collective social actions of socio-political nature, which lead a part of the population to be organized around a common purpose (Gohn, 2011). According to this author, in any social movement there is an analysis of a given moment in history and the elaboration of a diagnosis of that moment, trying to present the solutions that make sense for the participants (Gohn, 2011).

Throughout contemporary history people have acquired rights of defense, which allowed them to use new forms of mobilization to acquire new rights. If initially strikes and demonstrations were considered public disorder, with the passing of time have become vested. in the public sphere exhibited new social movements with innovative claims. To this contributed greatly decreased State repression of these manifestations.

Thus, we begin by analyzing the movements of the nineteenth century and continue the analysis until the twenty-first century in an attempt to give historical significance to the social transformations resulting from the acquisition of the right of citizens to collectively expressed in public.

\section{The nineteenth-century social movements}

The social unrest has been constant throughout Portuguese history, generating various types of social movements, depending on the period in which they occurred. The transition from the Old Regime to Liberalism in Portugal led to riots, similarly to what happened in other parts of Europe, as shown in the work of authors such as Eric Hobsbawm and Edward Thompson, who considered these riots as "archaic" or "pre-modern" movements. These protests were due to the confrontation between the traditional way of life and the modern capitalist system of social organization.

People who had not been born or raised in a modern or capitalist world were facing the penetration of the relations of production and the logic of capitalism in their traditional world. The confrontation between these two realities led to conflicts, 
in which kinship and other tribal bonds were of high importance in terms of the delimitation of the groups in confrontation, was expressed in an archaic form and had no political pretensions.

This social movements occurred due to the attempt of the people to adapt themselves or due to their inability to adapt to the new reality. Among those movements Hobsbawm studied the Social Bandit, revolutionary peasantry movements of the Millenarianism kind and rural secret societies (Hobsbawm, 1978).

Within the same type of pre-modern revolt are also the food riots, studied by Thompson to England (1979: 62-134).

The ones who took part in those primitive movements hadn't found a specific language to express their aims about the world yet and therefore their actions were considered pre-political. Their culture was mainly oral because they were illiterate in the majority (Hobsbawm, 1978).

This pre-modern agitation wasn't either often analyzed, or recognized as having any kind of importance, because it can't be included in the patterns of the modern social movements, the ones that took place in the last part of the 18th century. This kind of agitation could more likely be included in the occasional phenomena that happened in the Middle Age. But the truth is that it was a reality in the 19th and 20th centuries, happening at the same time as the modern protest movements.

These people, who weren't born or raised in a modern or capitalist world, had to face the production relationships and the capitalism logic that interfered with their traditional world. The confrontation of these two realities caused conflicts, expressed in pre-modern terms and with a pre-political language.

These societies, though pre-industrial, were aware of the State, the class distinctions, and the exploitation by landowners and merchants for a long time; therefore, their protest was already a class protest. The fact that there were kinship ties and tribal solidarities is what frames these societies within the primitive ones, though there was class consciousness. The authors cited above were precisely interested in the fact that these movements were class movements.

According to Thompson, the confrontation with a new capitalist practice changed the 'moral economy' that governed the traditional market practices in the eighteenth century, broke the paternalistic tradition, and gave rise to social movements.

In Portugal, there were various social movements considered "pre-modern" in the first half of the nineteenth century (Silva, 2007). Phenomena such as banditry or food riots occurred in the period of the implementation of the liberal and capitalist society. The political and social unrest that occurred after 1834 maintained and fostered this social phenomenon, and large groups of bandits, who became famous for their violent and courageous acts, were formed everywhere in the country. Among them, we highlight the Marçais in Douro, the Brandões in Beiras, and the Remexido in the Algarve (Ferreira, 2002). Banditry, though it was not a typical social movement, had to be considered a social phenomenon, because, in spite of being marginal, it was important as a collective action of a group of individuals who defied the established order (Hobsbawm, 1978:12), in an attempt to perpetuate the past, as their biggest problem was their adaptation to the new world they were facing. Likewise, the liberal state, when appointing to regional administration positions individuals who were not from those same regions, created a certain distance between the local authorities and the populations, which facilitated the introduction of the capitalist market laws, without complacency for the traditional moral of the people, generating food riots (Silva, 2007). Even in the country's capital, Lisbon, in 1856, people went to the streets to protest against the high price of the bread and the abusive practices of the merchants (Roque, 1985).

Though these protests occurred in the nineteenth century, they resorted to forms of collective action that were reminiscent of the Old Regime: gatherings of crowds after ringing bells, mediation of conflicts by local elites, attacks on public buildings, in a non-organized way.

One of the arguments that have been used to differentiate the traditional forms of protest from the modern ones is that the former do not undermine the foundations of the established social order and contribute to maintain and strengthen traditional and paternalistic ways of life, as stated by Thompson. Moreover, as these protests did not give rise to modern, organized, and politicized social movements, they must be considered and classified as pre-political and reformist movements, not revolutionary ones (Hobsbawm, 1978).

Although these ways of collective action were labelled as "traditional", "primitive" or "pre-industrial", seeming a remaining of the past, they show in the first half of the 20th century a clear importance of the popular within the social protest. At the same time the economic, political and social changes led to new ideas and experiences that would affect the society in an intense and permanent way, changing the features and ways of conflict. The progressive political reforms, the rising of capitalism and the modernization of a country due to industrialization, although weak and late, determined the gradual disappearance of the old forms of protest, since the persistence of customs and rights of the past didn't make sense in a world which was constantly changing. The local, spontaneous, sporadic and non-political manifestations were replaced by 
modern protests with national ideologies. It is yet obvious that this change from the old to the new wasn't that simple. It had different features according to each region. The transition from the traditional to the contemporary society took place at least throughout the whole $20^{\text {th }}$ century.

According to Charles Tilly's terminology, the movements started as "reactive" ones, including the defensive practices in the face of external pressures (food riots, anti-fiscal protests, resistance to military service, hostility to machinery, land occupations, etc.) and became "proactive" actions, mainly from the mid-nineteenth century on, i.e., more organized forms linked to an associative base: strikes, demonstrations, trade unions (Tilly, 1978:143-155).

Actually, new forms of protest arose, motivated by the gap that was created between capitalists and workers, as the Portuguese industrial development was taking place (second half of the nineteenth century) and the social relations were changing due to the capitalist mode of production. This group of workers became stronger with time, gaining class consciousness. Associations of workers, and later trade unions, were formed. in Portugal, as in Europe, the first associations of workers had a mutualistic character, with a cultural purpose and promoting mutual support (Cabral, 1988), as sickness and death assistance, a memory of the ancient brotherhood crafts. This was the only possibility of association, since crafts associations were not allowed in Portugal until 1891.

This associative movement strengthened the organization of the workers, giving rise, in the second half of the nineteenth century, to a distinct type of social movement, the strike, in which there was a conflict situation between workers and their employers. This conflict was motivated by the low wages, excessive working hours, and poor working conditions.

In order to demonstrate their dissatisfaction and claim for better living conditions, the workers would cease work and protest, whether or not they were members of any association. By breaking the daily working relationships, the strike created a division, highlighting the class conflicts, and, even if it was generated by economic discontent, in the end, it united strikers and militants of different parties, becoming a means of ideological propaganda.

The Portuguese labor movement was strong in the late nineteenth century, and especially in the early twentieth century, because in 1910 the Republic was set in Portugal and the right to strike was decreed, as long as the strikes did not mean disrespect and violence against those who wanted to work. During the First Republic (1910-1926), consecutive strikes were promoted in various industrial activities: textiles, metallurgy, dyeing. The workers' demands were identical to the ones in the monarchic period: better wages, reduced working hours, and the introduction of machinery in the factories.

The labor movement became the expression of the conflict generated within the industrial society, between employers and employees.

The labor movement, considered a modern movement, lost its spontaneity; strikes did not appear and disappear as quickly as before and could last for days, weeks or months, depending on the confrontation and complaints. It became an organized movement that aimed at the acquisition of better pay and working conditions, moving from economic and social demands to political ones, especially when movements started being organized by unions. Trade unions gave legitimacy and legal framework to the strikes, whether they were professional or general strikes. in the latter, the political character was well evidenced. in Portugal, there were some associations with federalist and union character, but only after the legalization of associations.

Both the primitive movements of the early nineteenth century and the strike movements of the second half of the century, though different, had a common feature: the protest against the country's economy and society. The first movements corresponded to forms of protest against the inadaptation to a liberal and capitalist world, which disregarded the traditional way of living. The second ones were the reaction to the exploitation caused by a profit-oriented capitalism, which had on its base the bourgeois class that also dominated politics. The forms of protest that were used were completely different: the first ones were "reactive" and the second ones were "proactive".

\section{Social movements in the dictatorship period (1933-1974)}

The Dictatorship which was settled in Portugal with the State attack that took place on the 28th May 1926, had its apogee with António de Oliveira Salazar's Regime, known as the New State (1933-1974).

Salazar was in favour of a policy that refused the parliamentary and liberal past, since, according to him, only a change in the political, administrative, economic, social and cultural conditions could allow the rebirth of the Portuguese Nation (Salazar, 1928-33). Therefore he established the corporate nationalism, the social and economic intervention to develop a strong State. 
From then on the ideals of Salazar's Dictatorship are confused with the ones of the other European Dictatorships, in spite of the Portuguese singularities. in fact, as Braga da Cruz points out, the New State wasn't theoretically totalitarian or, at least the doctrine didn't assume that way (Cruz, 1988, p.52).

Salazar ruled for forty years, despite the obstacles he had to face. for him the most important concepts, the ones he took for granted were "God", "Homeland", "Authority", "Family", Work". These were enduring values that couldn't be discussed by the Press or by any other sector of the public life. in the last years of the New State the resistance to this Dictatorship started to arise.

When Marcelo Caetano was chosen to be the Prime Minister after António de Oliveira Salazar, in 1968, he followed a policy of "evolution in the continuation", hence destroying the expectations of a change in the Regime. in fact, Marcelo Caetano followed Salazar's ideas, trying to make them seem more modern. But the strong authoritarian ideas against the existence of different political parties still existed, as well as the colonial war1. and the colonial war was in fact the reason why there was a military revolution on the 25th April, 1974. This revolution led to a Democratic Regime in Portugal.

During the dictatorship period, the social movements followed the same line of protest of the First Republic, though public demonstrations and strikes were prohibited. Nevertheless, even without legal authorization, there were movements organized by peasants and workers; they occurred in a smaller scale, but were much more intense due to the violent repression.

In the 1940s, despite the existence of a political police in the country, acting brutally and without judicial tutelage (Madureira, 2007), the protests of the workers, both in the cities and rural areas, started once more, due to the lack of food and poverty in which they lived. There were major strike movements in 1942, 1944, and 1947.

The World War was taking place, it was difficult for the country to import food and the people in the cities and rural areas were protagonists of several riots for subsistence, demanding food from the authorities (Rosas, 2000), and strikes in the factories.

These movements were not allowed, they were illegal, and soon became coordinated by the Portuguese Communist Party, also prohibited and clandestine and blaming the regime for the misery the workers lived in.

The Salazar government responded to the strikes through military occupation of the factories, bypassing the authority of the employers, the deportation of the leaders, and the conditioned readmission of the strikers (Raby, 1988). This repression was so effective that the workers who participated in the strikes did not repeat their action in the following years even though they were in penury (Rosas, 1990). The strikers who resisted were able to taste the subversion of the dictatorship, backed by the Communist Party. At the same time, groups of people resisting the authoritarian state were arising, but, as the demonstrations increased, the repression intensified. in 1944, during the workers' strike in Lisbon, hundreds of workers were detained and placed in the bullrings of Lisbon and Vila Franca de Xira. There, the police tried to separate the leaders and punish the other workers, delaying their reintegration at work (Cerezales, 2011).

The movements in the countryside created the first victim of the system. in 1954, a peaceful demonstration of peasants, who claimed for better wages before their employers, led the police to fire at close range at a peasant girl, who entered in history, becoming a martyr and symbol of the brutality of the Salazar regime (Godinho, 2001).

The sixties brought social change to a country closed by dictatorship. Emigration and tourism were responsible for the acceleration of this change as they allowed the Portuguese to have contact with the Western democracies. Moreover, as far as the political context was concerned, there were also expectations of openness due to the replacement of António Salazar by Marcelo Caetano. Hopes dashed.

The continuity of the dictatorship led to the maintenance of protests and to the arising of new social movements as the students' movement. The contact with other realities led students to unite and fight for freedom of association, the end of the colonial war, and the openness of the civil society to the students' academies. These students demonstrated against the war as a principle, they were not only considering the Portuguese colonies' war. in 1968, they gathered outside the Embassy of the United States against the war in Vietnam. These protests were violently repressed, but they strengthened the students' movement (Cerezales, 2011).

As this movement of students was developing, the workers, simultaneously, were leaving their lethargy, triggering various sectoral struggles over wages; there were no general strikes, but they organized standstills in different activity sectors.

1 At this time Portugal was facing the war of its overseas colonies that wanted to become independent 
Before these protests, the government tried to frame the workers in the trade union movement and started facilitating collective bargaining.

While the students' movement was still being organized, the labor movement was becoming stronger due to its framing within trade unions.

The social movements in the dictatorial period acted illegally and were supported by underground parties, but it is not possible to say that they were politicized.

\section{Social movements in a time of Democracy}

As the expected political renewal failed and the colonial war persisted, there was a clear feeling of discontent within Portuguese society, namely among soldiers who were sent overseas to fight a war they no longer believed in. On the 25th of April 1974, the Portuguese captains organized a military coup that brought down the dictatorship and led the country to democracy.

The Revolution that led Portugal to Democracy started with the appropriation of the means of communication: the Portuguese Radio Clube, the National Radio and the National Television by the military forces. (MFA). The rebellion started when the announcer João Paulo Dinis, according to the instructions received from Captain Otelo Saraiva de Carvalho, played the song "E depois do adeus", by Paulo de Carvalho, five minutes before eleven o'clock p.m. (Ferreira, 1993). It was the signal for the troops to set forth and they did that very quickly. The Captain Salgueiro Maia, responsible for the School of Cavalry in Santarém, arrived in Lisbon in a record time: two hours. (Ferreira, 1993). Twenty-five minutes after midnight Renascença Radio played the song, Grândola Vila Morena, by Zeca Afonso. It was the confirmation that everything was happening as it had been planned.

At around three o'clock in the morning all other means of communication were already controlled by the troops. Those means of communication were always advising people to stay calmly at home, waiting for the news about the revolution that had been started by the military forces to put an end to the Regime.

The Government only reacted to the appropriation of the Radio on the following morning, by ordering the cut of the electric energy and of the telephones of Radio Clube (Ferreira, 1993).

The rebellions quickly solved the problem and their communication went on the radio and later on television. Actually the strategy used by the leaders of the operation "Regime-ending" of transmitting constant communications to the population was perfect, since they convinced the population who came out to the streets to support the military forces.

The first social movements in a time of democracy were the peasants' movements; they occupied the lands of major landowners, forcing an agrarian reform (Fernandes, 2002).

The workers, who were then allowed to participate in strikes, were called for a general strike on the 12th February 1982. The strike, which lasted 24 hours, was organized because of a project of constitutional reform the government was preparing at the time $(A D)$, which would eliminate the reference to the agrarian reform from the Constitution.

The general strike initiative was organized by one trade union (CGTP), with the support of the Communist Party. The other trade union (UGT) did not support the general strike. The Ministry of the Internal Administration, predicting there would be strike pickets to prevent workers from working, announced that the police force would be used to ensure freedom to work.

This social movement introduced a new way of action, typical of the latest movements - the use of media as a propaganda factor. Nevertheless, at that time there was only one television channel in Portugal, which belonged to the state, and, therefore, the government used it to tell the public opinion that the strike had insurrectionary assumptions.

Since then, there has been a change in the way of action of social movements; they are no longer restricted to public spaces, they can be followed by everyone who sees them on TV.

These social movements are organized and politicized; though they do not aim at a political revolution, they are linked to parties, trade unions and manifest themselves in the public sphere.

Since the turn of the century, we have witnessed a transformation in social movements and, in the twenty-first century, we have observed phenomena with peculiar characteristics, going beyond politics and questioning the way democracy itself is being exercised nowadays. The "main objective of democracy must be to allow individuals, groups, and collectivities to become free subjects, producers of their history, able to reunite in their action the universalism of reason and the particular features of personal and collective identity" (Touraine, 1995:.263). Social agents act now through demonstrations, non- 
institutional action processes, recruiting their actors in various social contexts. The aim is to become visible, to bring the public opinion to their cause, and have social repercussions. These new protagonists: youth, students, women, liberal professionals focus their struggle no longer on their living conditions or on the redistribution of resources, but on the quality of life and diversity of lifestyles.

It is not a protest in order to have more rights, but to exercise the already existing ones, full citizenship, which offers the freedom to express one's opinion and the privilege of participating in the political, economic, social, and educational areas. Several movements with these characteristics have occurred in Portugal, but we will highlight the movement which took place on the $12^{\text {th }}$ March, 2011 - "The Scraping-by Generation".

In this movement, individuals, as citizens, as people belonging to a collectivity, intervened in the public sphere and discussed issues related to them - the crisis, unemployment, exploitation.

According to its organizers, the $12^{\text {th }}$ March movement wanted the civil society to demonstrate its disapproval of various aspects of real life that they considered unworthy for citizens, by expressing themselves while an active part of a democracy. According to them, citizenship must not be limited to the Electoral Act.

On the $12^{\text {th }}$ March, through social networks, nearly 500 thousand people went to the streets to protest against job insecurity and the austerity measures imposed by the government.

The purpose was to promote a more participatory democracy. Social networks disseminated the feelings and opinions of varied sectors of society, concerning the government measures, the banking system, the crisis, the political class, making it clear that the ones who charge and the ones who pay cannot always be the same.

It was a movement that entitled itself as independent from any politic party, without affiliations to political parties and trade unions, secular, peaceful, and without a formal organization. Nevertheless, it suffered some repression, as the elites feared its effects, and there were confrontations with the police. The fact that it was not included in any organized structure was also a reason for concern, as it was a movement not limited to a group of young idealists, but involved several social groups that no longer believed in political parties to represent them.

According to Ana Cabo, these new movements are not very heterogeneous, their objectives are little negotiable, and they maintain an ambiguous relationship with the political power (2008: 51). They believe that change is made by new routes, without leaders nor bureaucratic organizations, but using solidarity.

These twenty-first century social movements are differently configured from the previous ones, in the form of organization, the size, the dissemination, and the national and international media coverage. All this escapes all previous models. It is through the social networks that they are organized and they can mobilize thousands of people in several cities in the same country or even different countries. They reach a size that exceeds the regional and national scales and become planetary movements, in a search for new forms of democracy (Antimo Farro 2004).

\section{Conclusion}

The forms of protest have followed the evolution of Portuguese society. From the moment the politics, economics, and society started changing, the same happened with the forms of protest, allowing the change and acquisition of rights. It is true that this transformation was not always immediate or visible at the time of the events, but it is possible to say that the movements were also actors in these transmutation processes.

Currently, there is no doubt that social movements act differently, using the technological means that have been placed at the service of humanity to promote meetings, to disseminate their ideas, to promote themselves. The network society is fully operating, even as far as the organization of protests is concerned, reflecting the reality of globalization.

The reasons have also become more complex; first people contested to maintain or acquire rights, now they claim for a new world. Therefore, today's movements are more complex, as stated by Melucci "many contemporary conflicts are the expression of socially excluded groups who want to be represented socially" (Melucci, 1996:104-105), questioning the whole political-economic-social liberal model.

In this century, the Social Movements have become promoters of social conflict due to their "institutionalization" as a social actor needed to improve democracy. Thus, from the nineties to the early twenty-first century, the social movements have acquired a key role as a political actor in a democratic state, due to their recognized importance as the legitimate holder and dynamic representative of the claims of different sectors of the civil society (Machado, 2007). 
The social movements in Portugal have acted as catalysers of change, and we will see the impact that the current movements will have as "agents of historical transformation".

\section{References}

[1] Almeida, M.A. (2006). A revolução no Alentejo. Memória e trauma na reforma agrária em Avis. Lisboa: Imprensa de Ciências Sociais.

[2] Cabo, Ana Isabel (2008). Os Novos Movimentos Sociais e os Media. Lisboa: Livros Horizonte.

[3] Cabral, M. (1988). Portugal na alvorada do século XX. Lisboa: Presença.

[4] Cerezales, D.P. (2011). Portugal à corunhada. Protesto popular e ordem pública nos séculos XIX e XX. Lisboa: Tinta da China.

[5] Cruz, M. B. (1988). O partido e o Estado no salazarismo. Lisboa: Ed. Presença.

[6] Farro, A. (2004). "Actors, conflits and globalization movement". Current Sociology. Vol.52. Londres: Sage.

[7] Ferreira, J. M. (1993). Portugal em Transe (1974-1985). in J. Mattoso (Eds.), História de Portugal (vol.8). Lisboa: Círculo de Leitores.

[8] Fernandes, A. T. (1993). "Conflitualidade e Movimentos Sociais". Análise Social, vol.XVIII (123-124), pp.787828.

[9] Ferreira, M.F.S.M (2002). Rebeldes e Insubmissos. Resistências populares ao liberalismo (1834-1844). Porto: Afrontamento.

[10] Godinho, P. (2001). Memória da resistência rural do Sul. Lisboa: Celta.

[11] Gohn, M.G. (2011). Movimentos Sociais na contemporaneidade. Revista Brasileira de Educação. Vol.47,pp.333-361.

[12] Hobsbawm, E. (1978). Rebeldes Primitivos. $2^{a}$ ed. Rio de Janeiro: Zahar Editores, 1978.

[13] Machado, J. A. (2007). Ativismo em rede e conexões identitárias: novas perspetivas para os movimentos sociais. Sociologias, $n^{0} 18$, Julho-Dezembro. Porto Alegre.

[14] Madeira, J. ed. (2007). Vítimas de Salazar. Lisboa: Esfera dos Livros.

[15] Mellucci, A. (1996). Challenging codes - collective action in the information age. Cambridge: University Press of Cambridge.

[16] Mónica, M.F. (1986). Artesãos e Operários. Lisboa: Edições do Instituto de Ciências Sociais.

[17] Offe, C. (1992). Partidos políticos e nuevos movimientos sociales. Madrid: Editorial Sistema.

[18] Pereira, J. P. (1982). Conflitos sociais nos campos do sul de Portugal. Lisboa: Europa-América.

[19] Pereira, J. P. (2001). Álvaro Cunhal. Uma biografia política. Lisboa: Temas e Debates.

[20] Raby, D. L. (1988). Resistência antifascista em Portugal. Lisboa: Salamandra.

[21] Roque, J.L. (1985). Subsídios para a História da revolta em Portugal no século XIX. Revista de História das Ideias. Coimbra, nº, pp.243-281.

[22] Rosas, F. (1990). Portugal entre a paz e a guerra: estudo do impacto da II Guerra Mundial na economia e sociedade portuguesas (1939-1945). Lisboa: Estampa

[23] Silva, C. T. (2007). Movimentos sociais no Douro no período de implantação do liberalismo (1834-1855). Porto: Gehvid.

[24] Tilly, C. (1978). From Mobilization to Revolution. New York: Random House.

[25] Tilly, C. (2004). Social movements (1768-2004). Londres: Paradigm Publishers.

[26] Thompson, E. (1979). "La Economia «Moral» de la multitud en la Inglaterra del siglo XVIII". Tradición, Revuelta y Consciencia de Clase. Barcelona: Crítica.

[27] Touraine, Alain (1995). La producción de la sociedad. Mexico: Ilsunam. 